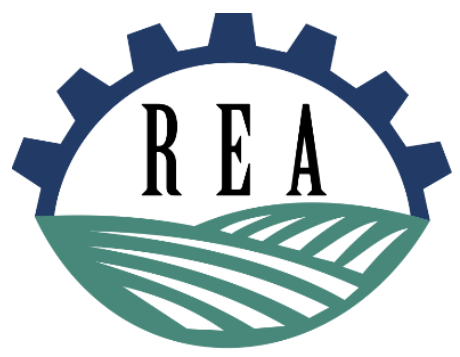

Revista de Economia e Agronegócio - REA ISSN impresso: 1679-1614 ISSN online: $2526-5539$ Vol. 15 | N. 3 | 2017

\section{AMAPÁ: A NEW GRAIN AGRIBUSINESS}

FRONTIER

\author{
1 Universidade Federal do Amapá, \\ Departamento de Meio Ambiente e \\ Desenvolvimento \\ * cfchelala@gmail.com \\ Cláudia F. Chelala ${ }^{1^{*}}$ \\ Charles A. Chelala'
}

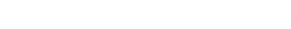

\section{ABSTRACT}

The search for new land for agribusiness to expand remains in Brazil, and Amapá state has recently become one of the new frontiers of the country. As in other geographical spaces engaged with agribusiness, Amapá also has its uniqueness, represented by the fact of being a state with reduced agricultural tradition, great participation of the public sector in the economy, and high percentage of its land transformed into specially protected spaces. On the other hand, it presents an area with savanna vegetation (the Brazilian Cerrado) that has been little explored, cheap land, and a strategic geographical location. This article analyzes the process of introducing agribusiness in the state, highlighting the limitations to its development and the potentials capable of transforming the productive sector of the state.

Keywords: Agricultural Frontier; Agribusiness; Amapá.

\section{RESUMO}

A busca por novas terras para a expansão do agronegócio é um movimento que se mantém presente no Brasil até os dias atuais e o estado do Amapá, muito recentemente, tornou-se uma das novas fronteiras do país. Assim como nos demais espaços geográficos ocupados pelo agronegócio, o Amapá também possui as suas singularidades, representadas pelo fato de ser um estado com reduzida tradição agrícola, grande participação do setor público na economia e elevado percentual de suas terras transformadas em espaços especialmente protegidos. Por outro lado, apresenta uma área com vegetação de Cerrado pouco explorada, terras baratas e uma localização geográfica estratégica. Este artigo analisa o processo de introdução do agronegócio no estado, destacando as limitações para o seu desenvolvimento e as potencialidades capazes de transformar o setor produtivo do estado.

Palavras-chave: Fronteira Agrícola; Agronegócio; Amapá. JEL Code: Q13. 


\section{INTRODUCTION}

Amapá state has an economy strongly linked to the activities of the public sector in all its spheres. The composition of the state gross domestic product (GDP) reveals that this segment represents $47 \%$ (of the $88.6 \%$ of the service sector) of the total wealth generated in Amapá. The productive sector is still incipient. Primary sector activities account for $2.23 \%$ of the GDP, and industry contributes $8.1 \%$ to the composition of the economic structure (IBGE, 2016).

In addition, it stands out in the national environmental scenario as one of the most preserved states in Brazil, with $73 \%$ of its territory as specially protected areas (DRUMMOND, 2008) whose symbol of this mosaic is the Tumucumaque Mountains National Park, the largest national park with $38,464 \mathrm{~km}^{2}$.

These two characteristics - the great participation of the public sector in the economy and the high percentage of land transformed into protected areas - represent apparently limiting factors for the development of grain agribusiness in the state.

A considerable part of the local economic system is related to the activities of the public sector, either by the number of labor force employed or by the purchasing power that the state has, represented here by all spheres: federal, state, and municipal. It is often said that the economy of Amapá is that of the "paycheck", referring to the fact that commercial activities are only heated during the payment period of the civil servants' salary. A study published in 2009 entitled "The magnitude of Amapá state in its socioeconomics" elaborated the "magnitude index of the state", according to which Amapá emerged as the federation unit with the highest presence of the government in socioeconomics among the other ones in Brazil (CHELALA, 2009).

However, at the other end, Amapá has important variables capable of boosting the agricultural activity that are interconnected to locational factors, such as the closeness of the region with savanna vegetation (in Brazil, called Cerrado) to the port area and the strategic geographic location in relation to the outflow of the production to the international markets.

Although Amapá is officially in the Amazon biome, there are vegetal phytophysiognomies of Cerrado in the eastern portion of the state called "Amapá Cerrado". In the last years, it has been transformed into one more frontier of the expansion of grain agribusiness in the country, like the one that already takes place in the region called "Matopiba", which is an acronym created with the initials of the Maranhão, Tocantins, Piauí, and Bahia states, a region of recent agricultural expansion, as well as Sergipe state.

This fact is very recent. In 2012, there was no soybean crop in Amapá. Just five years later, in the current year of 2017, approximately 19,000 hectares of soybean plantations are already identified, which are expected to 
produce 54.4 thousand tons of grain (IBGE, Municipal Agricultural Research 2015, and LSPA 2017).

Compared to the areas destined to soybean production in the country, these figures may be modest; however, this is a phenomenon that is rapidly advancing and has the capacity to modify the profile of the economy in Amapá, although there are important challenges to be overcome, especially in a state without agricultural and business tradition.

The objective of this study is to analyze the establishment context of the introduction process of grain agribusiness in the Amapá Cerrado region, as well as the prospects of its development.

The study is divided into five parts. The first one is the introduction and the second is a brief characterization of Amapá state, rescuing historical issues of its formation, geopolitics, and physiographic and demographic aspects. The third part - called the "discovery" of Amapá by grain agribusiness presents the process of introducing the culture in the region. The fourth section of the article addresses the prospects of grain agribusiness and the challenges to be faced by the segment. The fifth part is devoted to the final considerations.

\section{CHARACTERIZATION OF AMAPÁ STATE}

Amapá was constituted from the dismemberment of the northern part of Pará state in 1943. After 45 years as federal territory, it was elevated to statehood with the promulgation of the Federal Constitution of 1988. In 1990, it elected its first governor (formerly there were auditors nominated by the federal government) and its first Legislative Assembly, it extended its bench of federal deputies from three to eight, and it elected senators for the first time (DRUMMOND; PEREIRA, 2007, p.66).

The area of Amapá state is $142,827,897 \mathrm{~km}^{2}$, which corresponds to $3.9 \%$ of the North region and $1.65 \%$ of the Brazilian territory. It borders the north and northwest with French Guiana $(655 \mathrm{~km})$ and Suriname $(52 \mathrm{~km})$, making a total of $707 \mathrm{~km}$ of international borders. To the west and southwest, Amapá borders Pará state $(1,093 \mathrm{~km})$, most of it along the Jari River. Being located in the Amazon River delta, it presents a unique combination in the Amazon (only comparable to Pará) with marine and river coasts.

The southeast coast, along the left bank of the north channel of the Amazon River, forms a $315 \mathrm{~km}$ long coastal strip. To the east and northeast, the state has $598 \mathrm{~km}$ of ocean coast, corresponding to $8.11 \%$ of the Atlantic coast of Brazil.

The population estimated by the IBGE in 2015 is 766,679 inhabitants, of which 59\% reside in the capital Macapá and 15\% in the neighboring port city Santana. It is noteworthy the fact that $74 \%$ of the population is concentrated in only two cities in the same metropolitan region, only $13 \mathrm{~km}$ away from each other. Taking into account the entire population of the state, it is observed that $90 \%$ of the residents are in urban areas (IBGE, 2010 
Census 2010). The demographic dynamics of Amapá state shows the highest rate of population growth in the country, as shown in Table 1.

Table 1. Comparative population growth: Brazil, North Region, and Amapá state - 2000 and 2010 Censuses

\begin{tabular}{lccc}
\hline \multicolumn{1}{c}{ Region } & $\begin{array}{c}\text { Population in } \\
2000\end{array}$ & $\begin{array}{c}\text { Population in } \\
2010\end{array}$ & $\begin{array}{c}\text { Growth (\%) } \\
2000-2010\end{array}$ \\
\hline Brazil & $169,799,170$ & $190,732,694$ & 12.33 \\
North Region & $12,900,704$ & $15,865,678$ & 22.98 \\
Amapá State & 477,032 & 668,689 & 40.18 \\
\hline
\end{tabular}

Source: IBGE, 2000 and 2010 Censuses.

The annual percentage of population growth has been declining relatively compared to the last decade of the last century, but it is still very expressive, as shown in Figure 1. Therefore, it is a population that grows sharply, concentrated in urban areas, and spatially in the metropolitan region of the state capital.

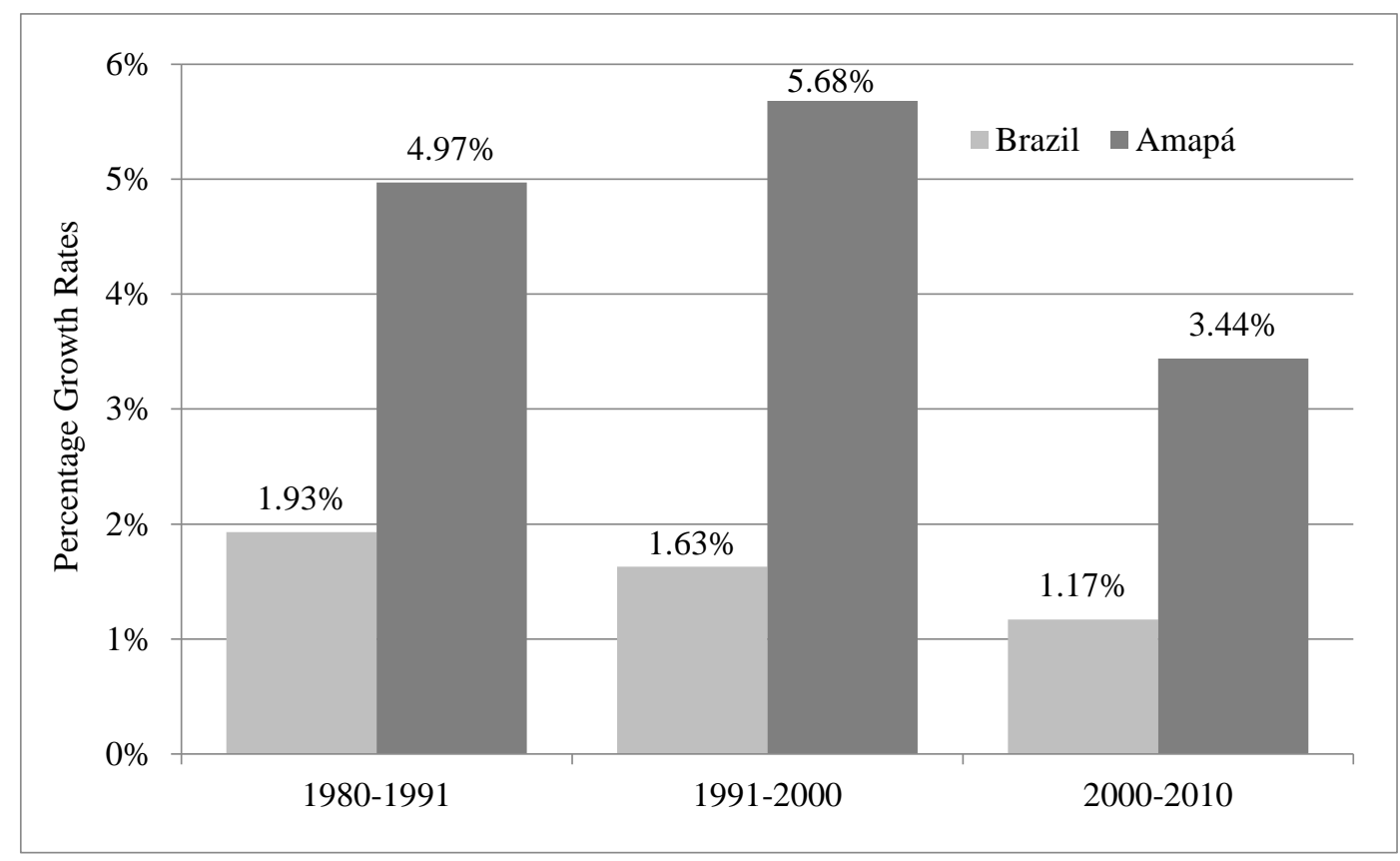

Figure 1. Comparison of annual percentage growth rates between Brazil and Amapá state and between the Demographic Censuses.

Source: IBGE, 1980, 1991, 2000, and 2010 Censuses. 
Regarding the floristic domains present in Amapá, the formation of savanna is the one that most interests the agricultural activity. The Cerrado of the state begins to prevail in the capital city Macapá, advancing in a range that varies from 50 to $150 \mathrm{~km}$ wide until approximately Calçoene, covering an area of about $374 \mathrm{~km}$, from which approximately $300 \mathrm{~km}$ are asphalted. In this route, Santana, Porto Grande, Itaubal and Tartarugalzinho are also included (AMAPÁ, 2014). With approximately one million hectares, Cerrado accounts for $6.9 \%$ of the total area of Amapá, which is marked predominantly by forest formations (Table 2).

Table 2. Area of the main floristic domains in Amapá (in hectares and percentage of the total)

\begin{tabular}{lcc}
\multicolumn{1}{c}{ Areas } & ha & $\%$ \\
\hline Total Area of Amapá & $14,345,370$ & $100.0 \%$ \\
Dense forests in dry land & $10,308,158$ & $71.9 \%$ \\
Floodplain forest & 694,981 & $4.9 \%$ \\
Forest transition & 391,536 & $2.8 \%$ \\
Mangrove & 278,497 & $1.9 \%$ \\
Savanna/Cerrado & 986,189 & $6.9 \%$ \\
Floodplain field & $1,606,535$ & $11.4 \%$ \\
\hline Source: Embrapa (2007). & &
\end{tabular}

In addition to the forests and the Cerrado, 1.9\% mangrove and $11.4 \%$ floodplain fields also comprise the floristic domains. The EcologicalEconomic Zoning of the Cerrado carried out in 2014 represents an important study to help the process of occupation of this domain in Amapá.

\section{THE “DISCOVERY” OF AMAPÁ BY THE SOY AGRIBUSINESS}

The history of extractivism and agriculture in the Amazon region predates the colonization period. The native products of the Brazilian forest with the drugs of the rural drylands (cocoa, cinnamon, vanilla, clove, Brazil nuts and guarana) attracted and settled people in the region during the seventeenth century. Then, the great economic boom, the 1st Rubber Cycle in the Amazon (1879-1912), ended up provoking an intense flow of migrants and a deep cultural and social transformation of the region. It is observed that the history of Amazon colonization is considerably associated to the exploitation of forest products, which is a typical feature of the regional identity.

In Amapá, it is not different. Brazil nut extractivism was one of the first commercial activities of the primary sector, and it continues to the present day with considerable relevance to the southern region of the state. With this, it is noticeable that agribusiness is not a recent activity. 
From the beginning of this decade, however, Amapá began to attract investors in the grain agribusiness segment. Figure 2 shows the exponential growth of temporary grain crops, notably soybeans, over the last five years.

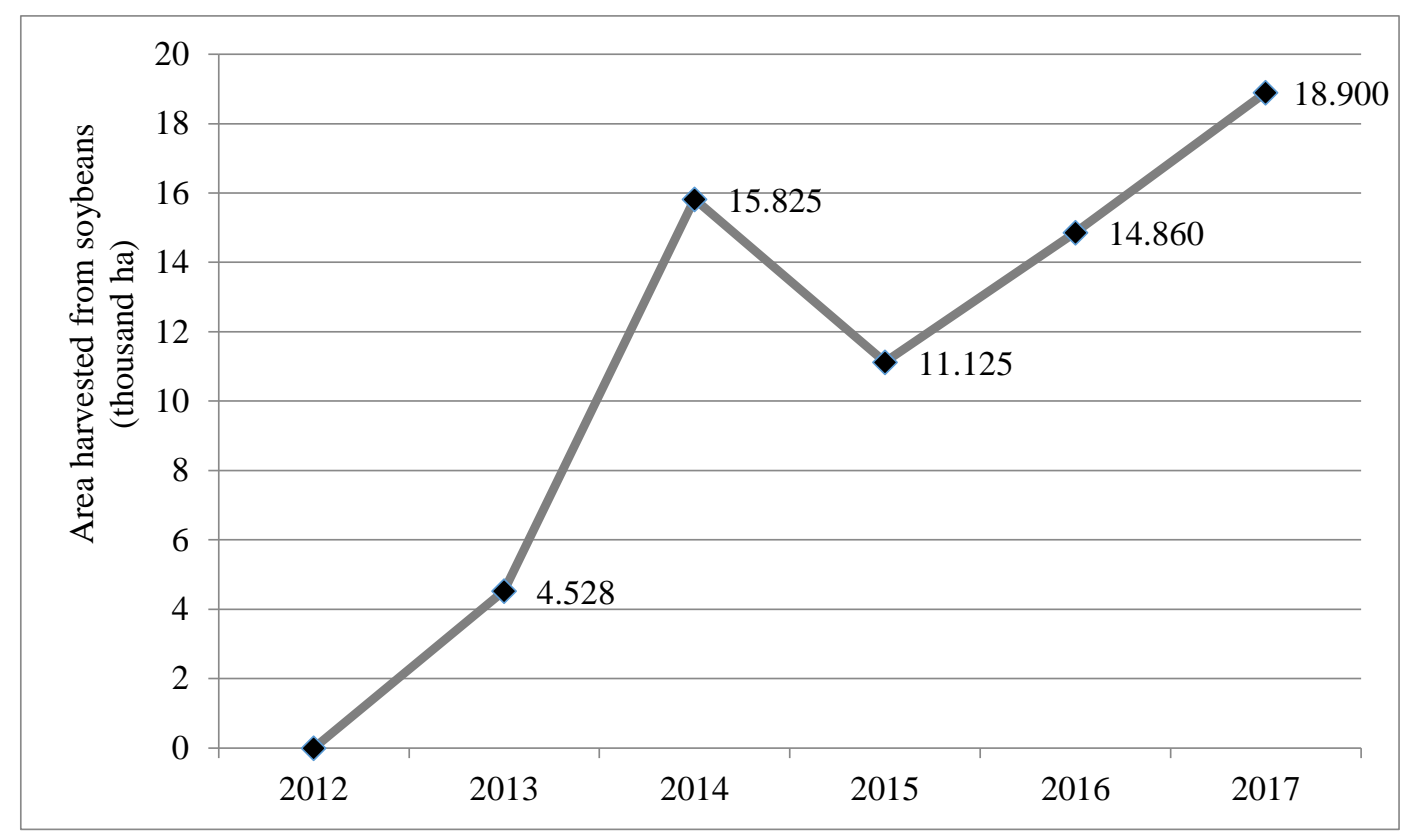

Figure 2. Evolution of the area in hectares where soybeans were harvested in Amapá.

Sources: IBGE, Municipal Agricultural Research (2012 to 2015). IBGE, Systematic Survey of Agricultural Production 2016 and 2017 (estimate).

Observing the curve of the harvested area of soybeans, it is possible to see that in 2012, no hectare of the crop was identified, but it reached 4.5 thousand ha in 2013. In the following year, the plantation growth was $249 \%$, being over 15 thousand ha. Despite the significant fall in 2015, the harvested area of the crop reacted in 2016 and has a strong growth forecast for the current year 2017, when it will reach about 19 thousand hectares.

From a production value point of view, the evolution of the income generated in this activity starts from zero in 2012 to $\mathrm{R} \$ 14.8$ million in 2013 and should reach a value higher than $\mathrm{R} \$ 64$ million with the harvest of 2017, as seen in Figure 3 below. 


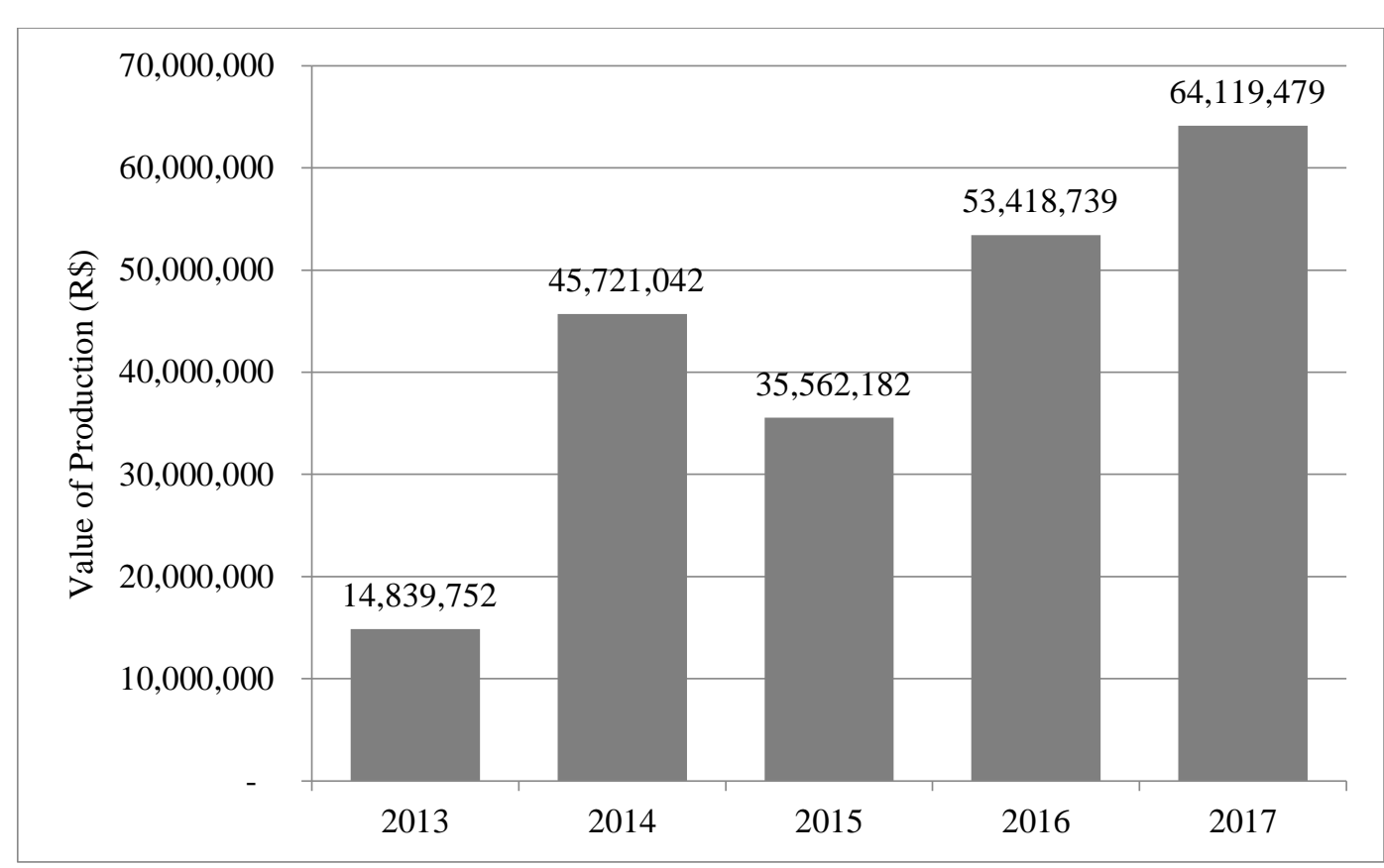

Figure 3. Evolution of soybean production revenues in Amapá (values in R\$).

Sources: IBGE, Municipal Agricultural Research (2012 to 2015). IBGE, Systematic Survey of Agricultural Production 2016 and 2017 (estimate).

Calculation of the value done by the authors based on the average annual price ascertained by the ESALQ/BM\&F Bovespa index of the Center for Advanced Studies in Applied Research - CEPEA for the 60kg sack of soybeans in bulk, export type, placed in the port of Paranaguá - PR state.

It is observed that, despite the expansion of production and income obtained from Amapá grain crops, this result was not reflected in the state trade balance, with US\$10.5 million total export share, or only $4 \%$ of the tariff in 2016 (SECEX-MDIC). This amount converted into reais would be approximately $\mathrm{R} \$ 35$ million, about $66 \%$ of the revenue effectively generated in 2016.

This fact can be explained by the still insufficient support structure and internal logistics, which prevents the direct export of local producers. Large exporters located in states such as Pará and Mato Grosso may have been acquiring the grain production from Amapá and inflating their exports with soybeans from this state.

In order to understand who are the pioneers of the grain agribusiness production in Amapá, Castro \& Alves (2014) published a field survey with 15 of the state's main grain producers. Their results showed that, although $67 \%$ of the farmers came from the three southern states of the country, more than half of them declared that their last source came from the states of Mato Grosso do Sul (33\%) and Mato Grosso (20\%). As it was also identified that $60 \%$ of the interviewees have more than 20 years of experience in agriculture, the authors verified that the agribusiness investors in Amapá are the second or third generation of producers in the traditional areas of Brazil: from the South, with branches in the Midwest, which are pioneering the new agricultural frontier. 
"This phenomenon intensified in the 1970s, when the children and grandchildren of the pioneers of commercial agriculture in Brazil were forced to seek new alternatives, since their properties became small with the generations" (CASTRO; ALVES, 2014, p.29-30).

Several factors have attracted these producers to Amapá. An issue related to the global logistics of grain production in Brazil can be highlighted initially as a result of the decision to implant the bulk terminal and grain processing industry in Amapá by the company Cianport, a joint venture of the big companies Agrosoja and Fiagril, which operate in Mato Grosso.

Cianport chose Amapá as a transshipment point for its production to replace expensive road trips to ports in the south-southeast of Brazil. This route along the Amazon River should provide a 30\% reduction in freight costs for producers in Mato Grosso according to the logics explained below.

Until very recently, all grain production in the Brazilian Midwest was shipped almost entirely in the ports of Santos (São Paulo state) or Paranaguá (Paraná state). Based on Sorriso, a town in Mato Grosso state, these ports are $1,950 \mathrm{~km}$ and $2,100 \mathrm{~km}$ away with precarious and congested highways. This same production would save between 850 and 1,000km of land to the port of Miritituba, in Itaituba, Pará state, via BR 163 highway (Cuiabá Santarém), in final paving stage. From there, the cargo follows in convoys of barges for $820 \mathrm{~km}$ of fluvial route to the port of Santana in Amapá. It is in this port where a set of silos for approximately 50 thousand tons of grain is implanted. The transshipment will be carried out for bulk carriers from there and, it is on Santana Island, on the other bank of the Amazon River channel that bathes the town, where the bulk terminal and the crushing grain industry will be implanted. Thus, the gain in competitiveness is double, either by the economy of land, or by the closeness of Amapá in relation to the main international ports.

The installation of Agrosoja and Fiagril in Amapá has aroused the interest of the producers of the Midwest to the possibility that the state is not only a center of transshipment, but also of grain production.

One of the greatest comparative advantages of Amapá is the land availability at a more competitive price than in other producing regions of the country. The Ecological-Economic Zoning (EEZ) of the Cerrado of Amapá concluded that approximately 176 thousand hectares of this domain can be used for agriculture, according to Table 3.

In Table 3, the sum of the total considered by the EEZ of the Cerrado does not include 249.3 thousand hectares owned by the company Amapá Celulose - AMCEL, in which it develops a eucalyptus forestry enterprise for the pulp-paper production chain. This is $26 \%$ of the total savannas in Amapá, excellent-quality land fully regularized. For this reason, AMCEL has been pressured to market part of this property in favor of grain agribusiness. There is a high opportunity cost due to the underutilization of the space of AMCEL, which plants eucalyptus in approximately 65 thousand hectares, while the other 184 thousand hectares remains with no 
productive activity. A brief comparison can be made: in 2016, the soybean crop generated $\mathrm{R} \$ 53$ million in 14.8 thousand hectares (see graphs 2 and 3). In the same year, the export of eucalyptus chips for cellulose generated revenues of approximately US\$ 50 million (SECEX - Ministry of Development, Industry and Foreign Trade, 2016) in 249.3 thousand hectares. Thus, the average yield of grain agribusiness is $\mathrm{R} \$ 3,594.80$ per hectare, while eucalyptus silviculture yields is only $\mathrm{R} \$ 701.97$ per hectare, considering the average dollar quotation of R\$3.50 in 2016.

Table 3. Agricultural aptitude of the Cerrado of Amapá

\begin{tabular}{lcc}
\hline Preferential Use & \multicolumn{2}{c}{ Quantification } \\
& Area (ha) & Area (\%) \\
\hline Land with aptitude classification GOOD for agriculture & $176,503.01$ & 24.47 \\
$\begin{array}{l}\text { Land with aptitude classification GOOD for family } \\
\text { farming }\end{array}$ & $72,052.45$ & 9.99 \\
$\begin{array}{l}\text { Land with aptitude classification REGULAR for } \\
\text { agriculture }\end{array}$ & $6,240.45$ & 0.87 \\
$\begin{array}{l}\text { Land with aptitude classification GOOD for cattle } \\
\text { raising }\end{array}$ & $62,770.36$ & 8.70 \\
$\begin{array}{l}\text { Land with aptitude NOT RECOMMENDED for } \\
\text { agricultural activity }\end{array}$ & $403,699.69$ & 55.97 \\
$\begin{array}{l}\text { Total } \\
\text { Soure: AMAPÁ }\end{array}$ & $721,265.96$ & 100.00 \\
\hline
\end{tabular}

Source: AMAPÁ (2014).

For the Association of Soybean Producers of Amapá (APROSOJA-AP, 2016), the EEZ of the Cerrado was very conservative in identifying 403,700 hectares as "land not recommended for agricultural activity". However, considering the study by AMAPÁ (2014), it would still mean that grain production might increase tenfold in relation to its current level.

When analyzing the natural aspects, the climatic factors, such as mean temperature, annual precipitation indexes, and relative humidity, they prove to be suitable for agricultural production. Regarding the soil characteristics, it is noticed that:

“(...) [they] have the same pattern, with high acidity, low organic matter content, exchangeable bases and phosphorus, high toxic aluminum values and, consequently, low base saturation. With this, a great commitment to the construction of the fertility of this soil is demanded through corrective practices such as liming, phosphating and the rational use of fertilizers" (CASTRO; ALVES, 2014, p.27).

These conditions enable the soybean productivity in Amapá to be $2,578 \mathrm{~kg}$ per hectare, which corresponds to 42 sacks of the product. Productivity is 
still timid compared to the national average $(3,011 \mathrm{~kg} / \mathrm{ha})$, but the local index reflects the limitations of crop pioneerism, for example: many farms at first planting, adjustments of seed strains for better adaptation to climatic conditions, and only one crop per year. Nevertheless, producers estimate up to twice the current production per hectare, outlining a scenario of 80 sacks/ha in the near future.

However, the main attraction is the closeness of the producing region in Amapá to the port of outflow. The greatest distance between a grain farm and the port of Santana does not exceed $300 \mathrm{~km}$. Most of this route can be accomplished by highway BR156, which in this stretch is paved and in good condition. Aprosoja-AP (2016) carried out a study on the competitiveness differential of the freight of the Amapá production (Table 4).

Table 4. Comparison of freight costs between Amapá, Paraná and Mato Grosso

\begin{tabular}{|c|c|c|c|c|c|}
\hline Amapá/AP & $\mathrm{US} \$ / \mathrm{t}$ & Paraná/PR & $\mathrm{US} \$ / \mathrm{t}$ & Mato Grosso/MT & $\mathrm{US} \$ / \mathrm{t}$ \\
\hline $\begin{array}{l}\text { Internal } \\
\text { Freight - } \\
\text { Average of } \\
\text { the producing } \\
\text { region to the } \\
\text { port }\end{array}$ & 15.00 & $\begin{array}{l}\text { Internal Freight - } \\
\text { Average of the } \\
\text { producing region } \\
\text { to the port }\end{array}$ & 45.00 & $\begin{array}{l}\text { Internal Freight - } \\
\text { Average of the } \\
\text { producing region to } \\
\text { the port }\end{array}$ & 105.00 \\
\hline $\begin{array}{l}\text { External } \\
\text { Freight - } \\
\text { From } \\
\text { Santana/AP } \\
\text { to } \\
\text { Rotterdan/Ho }\end{array}$ & 60.00 & $\begin{array}{c}\text { External Freight - } \\
\text { From } \\
\text { Paranaguá/PR to } \\
\text { Rotterdan/Ho }\end{array}$ & 80.00 & $\begin{array}{l}\text { External Freight - } \\
\text { From Paranaguá/PR } \\
\text { to Rotterdan/Ho }\end{array}$ & 80.00 \\
\hline Total Freight & 75.00 & Total Freight & 125.00 & Total Freight & 185.00 \\
\hline
\end{tabular}

Source: APROSOJA-AP (2016).

The conclusion of such study shows that, considering the average price paid per sack of soybeans and comparing freight costs, the producer installed in Amapá has a possibility of monetary gains 12\% higher than that of Paraná and $31 \%$ if compared to the a producer in Mato Grosso. Estimates are optimistic: gross operating margins of 40 and 38\% in soybean and maize production, respectively. 


\section{PROSPECTS OF AGRIBUSINESS IN AMAPÁ}

The prospects for grain agribusiness in Amapá are positive in several respects: at the macroeconomic level, the GDP at the market price of the state in 2014 reached $\mathrm{R} \$ 13.4$ billion, of which agriculture adds only $0.8 \%$ of the total, or $\mathrm{R} \$ 107.4$ million (IBGE, 2015). If the ongoing expansion process continues, and assuming that 205,000 hectares of Cerrado could be destined to the grain agribusiness, soybeans, corn, rice and cowpea beans can generate revenues of $\mathrm{R} \$ 1.7$ billion in today's values (ALVES; CASTRO, 2014 , p. 28). Considering the other constant conditions and abstracting $30 \%$ of intermediate products, it is worth saying that Amapá grain agribusiness could account for around 9\% of the state GDP in the medium term.

With such a volume of production and income, it is also possible to project a big expansion of employment generation in rural areas, where

“(...) soybean production employs two people per 100 ha planted. Maize production employs eight people, that is, an average of five workers for every 100 ha destined to the production of grains. If we consider a potential for planting grains of 300 thousand hectares of Cerrado in Amapá, the state will have the capacity to occupy a workforce of 15 thousand people, that is, more than $20 \%$ of the entire population (counting men, women and children) that was in the state's rural area in 2013. That is just in the direct work in the field. (...) for each job generated in the field, the grain production complex generates six other jobs, either in the previous sectors or subsequent to the production of these grains. In this sense, the amount of jobs generated by the potential of grain production revolves around 90 thousand direct and indirect jobs". (CASTRO, 2016)

In addition to the increase in the number of jobs created in the rural area of Amapá, the agribusiness expansion will also provide a qualitative growth in these jobs. The average remuneration currently paid by the segment in Amapá is over R $\$ 1.2$ thousand, more than twice the average income in the rural area ascertained by IBGE (CASTRO, 2016).

Considering the structure and demographic dynamics of the state of high growth with a strong urban concentration that has already been mentioned in this article, it is possible to affirm that, unlike the historical Brazilian movement of rural exodus, "the rational use of Amapá Cerrado with grain production should promote an urban exodus, that is, labor going from the city to the countryside, and strengthen the interior of the state" (CASTRO, 2016).

Another relevant aspect for the economy of Amapá is the connecting productive activities with grain production, enabling segments related to the planting and processing of grains, such as fish farming, poultry farming and swine farming that can become profitable due to cheap feed prices, which are a by-product of grain production. As the state acquires the vast majority of the animal protein it consumes from other units of the federation, with the exception of buffalo meat because it has the second largest herd in the country, the viability of local farming, particularly of poultry, swine and fish, will contribute to the development of new economic activities.

Regarding the issue of the size of the rural properties that are being destined to the grain agribusiness in Amapá, Article 206 of the State Constitution 
establishes this: "The alienation or concession, in any capacity, of public land to an individual or legal person, even that by an interposed person, shall obey the following without loss to the provisions of law: a) up to 15 fiscal modules upon approval of the land agency" (AMAPÁ, 1991). For larger areas, the concession becomes more burdensome and bureaucratic. This restriction limits the areas to 750 hectares per a tax payer number or a corporate taxpayer registry in the cities Macapá, Ferreira Gomes, Porto Grande, and Itaubal do Piriri (fiscal module of 50ha) and 1,050 hectares of the properties located in Tartarugalzinho (fiscal module of 70ha).

In Amapá, small and medium-sized properties are being installed. Aprosoja-AP (2016) informs that it has 23 associates, which makes an average of 800 ha per producer. This way, the agribusiness model that is being implemented in Amapá is more similar to that of Paraná state countryside, with a larger number of medium producers than the Central West, which is characterized by large producing properties and where more than the entire Cerrado area available for production in Amapá has only one owner.

One of the major concerns regarding the grain production is the environmental impact of the activity, particularly the pressure on the forest formations of the Amapá biome. Experience in other states corroborates this fear and requires careful consideration of the issue.

As previously mentioned, the interest in agribusiness lies on the Cerrado, which should be occupied in a maximum 400,000 hectares, representing less than $3 \%$ of the total land of Amapá. At this moment, the implantation of a soybean farm in a forest area with the adjacent costs of vegetation removal is unlikely and of reduced viability, besides the preservation as a legal reserve of $80 \%$ of the property, while, in the Cerrado, the legal reserve requirement is $35 \%$ of the total area. In addition, Amapá is characterized as the state with the highest percentage of land recorded with some type of restriction, which reaches approximately $73 \%$ of its total area between conservation units, indigenous lands and land settlements or quilombolas (DRUMMOND, 2008). Presently, any kind of pressure on the forest areas in Amapá is discarded.

Questions arise about the possibility of land conflicts between new producers and family farmers. This risk, although existing, is minimized by the fact that the family agricultural production in Amapá is organized mainly in riverine areas, with reduced production in the Cerrado. There is also a possibility of complementarity between the production of grain agribusiness and the preexisting family agriculture, since the inputs for agricultural activity are becoming cheaper. The limestone that, for instance, brought in large scale to Amapá had a reduction of approximately $60 \%$ in its practiced price before the arrival of grain producers in the state1. There

1 Such information was provided in an interview with Mr. Udimar Antônio Nissola, who is the owner of the company "Agrícola Cerrado" that supplies local producers with fertilizers and other inputs for production. 
is also the gain in competitiveness resulting from improvements in the infrastructure for the production outflow and new marketing channels due to the growth of the segment.

At this stage, there are two main obstacles to the development of agribusiness in Amapá: the support structure before and after the production, as well as the difficulty of land regularization of the properties.

As in other agricultural frontier regions, the pioneer producers bring in the site before the production and marketing support structure is installed. In the processes prior to production, the licensing for the activity is very hard to obtain, besides other difficulties, such as few implement suppliers, shortage of input supply, among others. The same difficulties are faced after harvest, with a lack of supply of grain storage and drying structures; all of the existing ones are private. The marketing chain is still in implementation, requiring a greater number of intermediaries until the export, along with the still incipient associativism, since there is no (or still insufficient) cooperative to act in order to facilitate these decisive stages for agriculture. Thus, the margin potential to be obtained tends to be lost in order to overcome these obstacles.

However, the most relevant setback that currently prevents a greater increase in agricultural production and economic sustainability refers to the restrictions on land legalization in Amapá. The Embrapa study identified that only $6 \%$ of grain producers in the state have the Definitive Land Title (CASTRO; ALVES, 2014).

This phenomenon, typical in the Amazon region, stems from the unavailability of legalizable land, a result of the history of the vacant lands of the Union that are transferred to the states in a complex and bureaucratic way. In the case of Amapá, the federal government transferred, by virtue of Law 11499/2009, twenty-three pieces of land that amount to approximately 4.5 million hectares or $3 \%$ of the total area of the state, including a large part of the Cerrado. This legal provision was enacted in April 2016 (Decree 8713, dated April 15, 2016) and until currently, due to the lack of definition of procedures and criteria by the state government, no hectare of the land transferred was titled, remaining juridical insecurity for the agricultural entrepreneurs of Amapá.

As a result, the producer is prevented from accessing official financing programs that could make the business more viable, such as those coming from the Northern Constitutional Fund (FNO), because of the lack of real guarantees for loans. Presently, a considerable portion of the grain production of Amapá is financed by buyers of the crop (such as Agrossoja and Fiagril), which stipulate the reimbursement in sacks of the products, making the financing of the production expensive. Overcoming this obstacle may enhance the development of grain agribusiness in Amapá.

\section{FINAL CONSIDERATIONS}

The new grain agribusiness frontier in Amapá is a consistent movement evidenced by the exponential increase in planted area and local production. 
It should be noted that the soybean planted in the state, as well as the expansion area for grain planting is located in the region of Cerrado vegetation, which was not occupied with any other productive activity. This observation is important, since when referring to Amazonia, there is a not very clear understanding about the mosaic of biomes that are part of the region. In some cases, there is the idea that the Amazon is reduced to the great forest, which does not correspond to the reality.

According to AMAPÁ (2014), there is about 276 thousand hectares of Cerrado land with good aptitude for large-scale agriculture. Approximately 120 thousand hectares that now belong to the existing forestry project in Amapá state and may be destined to grain production can be added to this land, too. This is the current trend of the expansion of the soybean production in Amapá.

It is observable that the pioneers of the segment are mostly from other regions with experience in agricultural activities, such as the southern and central-western states of the country. They brought and implanted a highproductivity rural production culture that was nonexistent in the state with few exceptions - until then.

The attraction of investors to Amapá stems from key factors in the business competitiveness, such as: existence of land at favorable prices, easy outflow, closeness to the port, location of the state in relation to dynamic world markets, and good natural conditions for production. The inclusion of Amapá in the national logistics of the soybean outflow via multimodal transport through the Amazon River channel decisively influenced this process.

The expansion of this new agricultural frontier is directed exclusively to areas of Cerrado, which has an extension of 986 thousand hectares in Amapá (6.9\% of the state). Of this total, an interval between 176 thousand ha (according to the EEZ of the Cerrado) and 400,000 ha (according to Aprosoja-AP, 2016) should be occupied by the grain agribusiness. Some portion of the 249 thousand hectares belonging to Amcel that are currently destined to eucalyptus silviculture for cellulose can also be added to such availability.

This potentialiaty is modest in the face of the 180 million hectares planted with soybeans and maize in Brazil, but may have a profound impact on the state economy, characterized by a strong predominance of the public sector, which accounts for $47 \%$ of the state GDP. It is estimated that agriculture can contribute $9 \%$ of Amapá GDP, currently at R $\$ 13.4$ billion, of which all agribusiness adds only $0.8 \%$. This new dynamic in the local economy has the potential of generating 15 thousand direct jobs and 75 thousand indirect jobs, besides being able to reverse the highly concentrated demographic structure in urban areas of the metropolitan region of the state capital.

The migration and settlement of the new agricultural producers in Amapá has been characterized by small and medium-sized enterprises, 
approximately 800 hectares on average per producing unit, which refers to similarities with the existing production model in Paraná state. Although in Amapá it is still necessary to move forward in terms of associativism, different from what happens in that state.

With regard to two socio-environmental aspects, it is noticed that conflicts over land tenure are reduced since preexisting farmers did not occupy the Cerrado, and the risk for agribusiness pressure towards the forest is minimal due to the fact that large part of this biome is protected by special restrictions.

Two are the biggest challenges faced by grain agribusiness in Amapá. Firstly, the incipience of the support structure of the pre- and postproduction phases, a phenomenon that is common in areas of border expansion, which has prevented these first harvests from being economically advantageous to the producers. This is because the extra cost required to meet these needs erodes the possible expected margins.

The greatest obstacle, however, is revealed in the land issue in Amapá, the result of a decade-old juridical-federal imbroglio, whereby land in the state is extremely difficult to legalize. This has a profound impact on the economic viability of grain agribusiness, increasing the financing of production and causing insecurity in the future investor.

The configuration of Amapá as another expansion frontier of grain agribusiness is part of a process that has occurred in the Amazon in recent decades, and which is transforming the economic matrix of the region, previously characterized predominantly by the vegetable and mineral extractivism.

\section{REFERENCES}

AMAPÁ, Governo do Estado. Zoneamento Ecológico-Econômico do Cerrado do Amapá. Estratégia para a Sustentabilidade e Desenvolvimento Inclusivo. Macapá, 2014.

AMAPÁ, IMAP. Instrução Normativa No 002 de 29 de agosto de 2008.

AMAPÁ. Constituição do Estado do Amapá. Macapá, AP: Assembleia Legislativa, 1991.

APROSOJA - AP, Associação dos Produtores de Soja-Amapá. Estado do Amapá: Potencial Agrícola. 2016. Disponível em http:/ / aprosojaap.com.br/Pot_agricola. Acesso em 10/04/2017.

BRASIL, Lei 11.949 de 17 de junho de 2009. Dá nova redação à Lei no 10.304, de 5 de novembro de 2001, que transfere ao domínio dos Estados de Roraima e do Amapá as terras pertencentes à União e dá outras providências. Disponível em: http:/ / planalto.gov.br. Acesso em 28.03.2016.

CASTRO, G.S.A.; ALVES, L.W.R. Cerrado Amapaense: Estado da Arte da Produção de Grãos. Macapá-AP: Embrapa Amapá, 2013.

CASTRO, G.S.A; ALVES, L.W.R. Produção de Grãos: potencial para geração de riqueza no Cerrado do Estado do Amapá. Macapá-AP: Embrapa Amapá, 2014. 
CASTRO, G.S.A. O futuro da agricultura amapaense. Disponível em https:// www.embrapa.br/publicacao/1018393/o-futuro-da-agriculturaamapaense. Acesso em 02.04.2016.

CHELALA, C. A. A Magnitude do Estado na Socioeconomia Amapaense. Rio de Janeiro: Editora Publit, 2009.

DRUMMOND, J.; DIAS, T. C. A.; BRITO, D. M. C. Atlas Unidades de Conservação do Estado do Amapá. Macapá: MMA/IBAMA-AP; GEA/SEMA, 2008.

ECOTUMUCUMAQUE. Estudo de Impacto Ambiental do Terminal Portuário de Uso Privativo - TPUP e Unidade Industrial para Armazenamento e Beneficiamento de Grãos - Ilha de Santana. Macapá, 2013

EMBRAPA

Amapá

http://www.genetica.esalq.usp.br/pub/seminar/GKYokomizo-200702PPT.pdf. Acesso em 02.04.2016.

INSTITUTO BRASILEIRO DE GEOGRAFIA E ESTATÍSTICA - IBGE. Coordenação de Contas Nacionais. Contas Regionais do Brasil: 2010-2014. Rio de Janeiro: IBGE, 2016.

REVISTA GLOBO RURAL, ed 286, junho de 2010. Disponível em http://revistagloborural.globo.com/GloboRural/0,6993,EEC17096622886,00.html. Acesso em 07.04.2016.

SECRETARIA DE COMÉRCIO EXTERIOR - SECEX - MDIC. Disponível em: http:// mdic.gov.br. Acesso em 28.03.2017. 